\title{
Optimal treatment for penile verrucous carcinoma: a systematic literature review
}

\author{
Dong In Jo ${ }^{1}$, Song Hyun Han', Soon Heum Kim ${ }^{1}$, Hye Young Kim² ${ }^{2}$ Hong Chung ${ }^{3}$ and Hong Sup Kim ${ }^{3 *}$
}

\begin{abstract}
Background: Verrucous carcinoma, a rare low-grade well-differentiated squamous cell carcinoma, is known for its favorable biological behavior and lack of metastatic potential. However, aggressive resection is problematic in terms of compromised function and aesthetics. Hence, more conservative treatments are needed. Methods: To identify the up-to-date general biological behavior, diagnosis, and treatment trends, we searched PubMed using the keyword "penile verrucous carcinoma" without restrictions on publication date. Results: Current treatments for penile verrucous carcinoma include wide surgical excision, seldom preventive lymphadenectomy, and conservative chemotherapy without surgery or local excision with safe margins. Despite the advent of partial penectomy to minimally impact function and aesthetics, affected patients experience psychosexual problems. Local excision can be used to save the penile shaft and glans penis without preventive lymphadenectomy or adjuvant therapy and can achieve good clinical prognosis with rare recurrence. Conclusions: To preserve the functional and cosmetic aspects, we recommend local excision, especially for tumors measuring $<3 \mathrm{~cm}$ and classified as stage $T 1$ according to the 2016 tumor node metastasis clinical and pathological classification for penile cancer.
\end{abstract}

Keywords: Local excision, Penile verrucous carcinoma, Squamous cell carcinoma

\section{Background}

Verrucous carcinoma, a rare low-grade well-differentiated squamous cell carcinoma (SCC), is known for its slowly compressive expanding warty growth and rare metastasis [1-3]. Aggressive treatment, such as penectomy, has been suggested based on the concept that penile verruca carcinoma (PVC) is malignant. In contrast, less aggressive treatment, such as local excision without preventive lymphadenectomy, has been suggested based on the concept that the biological behavior of PVC resembles that of a benign tumor. In patients who had undergone aggressive wide surgical excision of the glans penis and penile shaft, many functional, cosmetic, and psychosexual problems have been reported. To date, surgical treatment trends have been unclear regarding

\footnotetext{
*Correspondence: hskim@kku.ac.kr

${ }^{3}$ Department of Urology, Konkuk University School of Medicine,

Gukwon-daero 82, 27376 Chungju, Chungbuk, Republic of Korea

Full list of author information is available at the end of the article
}

the use of preservation surgery. Here we reviewed the literature to determine the most effective treatment for PVC and suggest best practices for treatment guidelines.

\section{Methods}

To summarize the prevalence, causative factors, diagnostic methods, treatment methods, clinical behaviors, diagnostic imaging techniques, and prognosis of PVC, we searched PubMed for relevant studies using the keyword "penile verrucous carcinoma" without restrictions on publication year and retrieved abstracts published in English that mentioned PVC diagnosis and treatment. The abstracts were screened according to inclusion and exclusion criteria. The inclusion criteria were presented cases and the corresponding treatment methods, microscopic diagnosis of PVC, availability of full text articles, and publication in English. The exclusion criteria were lack of tumor staging information and tumor staging beyond T2 (Stage T2 penile cancers are different from penile verrucous carcinoma and defined as invasive

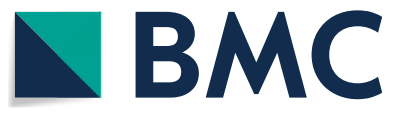

(c) The Author(s) 2021. Open Access This article is licensed under a Creative Commons Attribution 4.0 International License, which permits use, sharing, adaptation, distribution and reproduction in any medium or format, as long as you give appropriate credit to the original author(s) and the source, provide a link to the Creative Commons licence, and indicate if changes were made. The images or other third party material in this article are included in the article's Creative Commons licence, unless indicated otherwise in a credit line to the material. If material is not included in the article's Creative Commons licence and your intended use is not permitted by statutory regulation or exceeds the permitted use, you will need to obtain permission directly from the copyright holder. To view a copy of this licence, visit http://creativecommons.org/licenses/by/4.0/. The Creative Commons Public Domain Dedication waiver (http://creativeco mmons.org/publicdomain/zero/1.0/) applies to the data made available in this article, unless otherwise stated in a credit line to the data. 
cancers such as squamous cell carcinoma and others). To check the association between treatment method and conditions of cases, the treatments were categorized into 2 groups-the less aggressive treatment group included shaving, local excision, and no surgery and the aggressive treatment group included glansectomy, partial penectomy, and total penectomy. Individual factors included age, case history, tumor size, tumor shape, tumor location, tumor stage, adjuvant treatment, lymph node metastasis, disease-free status, recurrence, human papilloma virus (HPV) infection status, and treatment trends over time.

The statistical analysis was performed using SPSS for Windows version 25 (SPSS Inc., Chicago, IL, USA). We hypothesized that aggressive treatment is more effective and investigated the difference in efficacy between the 2 treatments. We performed a t-test, a chi-squared test, and Fisher's exact test to ensure data accuracy and a regression analysis to examine whether the individual factors were correlated in the 2 groups.

\section{Results}

A total of 276 articles were retrieved from PubMed. Among them, 68 abstracts that mentioned PVC diagnosis and/or treatment and were published in English were selected. The studies were published between 1969 and February 2019. Most of the studies were published in English; other publication languages included Spanish (14), Chinese (3), French (3), Japanese (2), Bulgarian (1), Israeli (1), and Italian (1). Several studies mentioned regarding PVC treatment and were simple case reports [4-47]. Its rarity is supported by the fact that 1 case in a 10 -year period and 13 cases in a 30 -year period were reported [10, 48-51]. Among the 68 studies retrieved, 28 met the inclusion criteria. Of those, 9 were excluded according to the exclusion criteria. Thus, a total of 19 studies were subjected to full-text review (Fig. 1) [4-7, $10,11,20,23,31,32,35,37-40,43,45-47]$.

The studies comprised a total of 58 cases of PVC (Table 1 ). The patients were $28-86$ years of age. The case histories were 1-204 months long. The tumor sizes were $0.8-10 \mathrm{~cm}$. Fifty- 4 of the cases included a description of tumor shape: papillary cauliflower in 30, keratotic hornlike in 3 , and warty verrucous in 21 . The tumors involved the glans in 33 cases, coronoid sulcus in 4, shaft in 4, prepuce in 7 , prepuce and glans in 4 , glans and coronoid sulcus and shaft in 1, prepuce and coronoid sulcus in 2, glans and coronoid sulcus in 2, and coronoid sulcus and shaft in 1. A total of 10 cases involved the coronoid sulcus, an area in which penile carcinoma would more rapidly infiltrate the penile fascia. Regarding staging, 52 cases were classified as stage Ta, 4 were classified as T1, and 2 were classified as T1a. Regarding treatment, no surgery was performed in 4 cases, local excision was performed in 10, shaving in 3, Mohs surgery was performed in 2, circumcision was performed in 1, glansectomy was performed in 3, partial penectomy was performed in 29 , and total penectomy was performed in 6 . Thus, 20 cases involved less aggressive treatment and 38 cases involved aggressive treatment. Fifteen cases of adjuvant treatment were reported, including 1 of radiotherapy, 6 of chemotherapy, 2 of chemoradiotherapy, and 6 of local therapy $\left(\mathrm{CO}_{2}\right.$ laser, cryotherapy, intralesional interferon, and topical fluorouracil). There was only 1 case of lymph node metastasis. The reported lymphadenopathies were revealed as inflammation without metastasis [4-6]. One case of bilateral lymph node metastasis, which was suspected as a mixed tumor condition with moderately differentiated SCC, was reported [35]. The follow-up period was 6-228 months (19 years). There were 7 cases of tumor recurrence: 5 in the less aggressive treatment group and 2 in the aggressive treatment group. All cases except 2 achieved tumor-free status. The other 2 patients died due to other malignant conditions [35, 47]. Six cases were associated with the following diseases: anaplastic spindle cell carcinoma suggestive of malignant transformation after radiotherapy, hybrid verrucous SCC, moderately differentiated SCC, lichen sclerosis, pseudoepitheliomatous keratotic and micaceous balanitis, and human immunodeficiency virus infection. HPV infection status was described as negative in 8 cases; the others were not specified. The reported cases following the year of issue categorized in 10-year increments: 1 in the 1970s, 14 in the 1980s, 2 in the 1990s, 15 in the 2000s, and 26 in the 2010s. The main diagnostic method was biopsy. Chest $\mathrm{x}$-ray, HPV polymerase chain reaction (PCR), ultrasonography, and computed tomography were optional. The best diagnostic method was biopsy and HPV PCR. Ultrasonography, computed tomography, and magnetic resonance imaging (MRI) offered more precise information about tumor anatomy and regional lymphadenopathy. Two reports mentioned surgical treatment guidelines according to tumor size [8] and depth [17]. Concerning surgical excision, the main treatment was radical surgery, including at least partial penectomy [447], even with the relatively small tumor size $(<3 \mathrm{~cm})$ [8]. The surgical margins were $2 \mathrm{~cm}$ in cases of partial penectomy and $0.3-1 \mathrm{~cm}$ in cases of local excision (Table 2) [5, 6]. In contrast, some studies have emphasized the good clinical results of local excision because of the favorable clinical behavior of PVC $[5,6,11,15,17,31,32,37,39$, 40, 43, 45-47].

The results of the t-test using categories of age, case history, and tumor size and the result of the cross-sectional analysis of the categories of tumor shape, diseasefree status, and HPV status were excluded since some 
Searching PubMed for relevant studies using the keyword "penile verrucous carcinoma" without restrictions on publication year $(n=276)$

Abstracts that mentioned PVC diagnosis and/or treatment and were published in English. $(n=68)$

Inclusion criteria $(n=28)$

1. Presented cases and the corresponding treatment methods.

2. Microscopic diagnosis of penile verrucous carcinoma.

3. Availability of full text articles, and publication in English.

Exclusion criteria $(n=9)$

1. Lack of tumor staging

information. $(n=5)$

2. Tumor staging beyond $T 2 .(n=4)$

Subjected to full-text review $(n=19)$

Fig. 1 The study flow chart

individual data for each case were missing (data not shown). In the cross-sectional analysis, tumor location, tumor stage, and recurrence were not significantly associated with either treatment. Regarding the clinical results, all but 2 patients (who died of other malignant conditions) achieved disease-free status. Regarding treatment efficacy, the recurrence rates did not differ significantly between the less aggressive and aggressive treatments.
Patients who received adjuvant therapy tended to ultimately receive less aggressive treatment. Regarding the test statistics, the $\mathrm{X}^{2}$ was 21.926 and the probability was 0.000 . Thus, the results were statistically significant. Regarding differences in treatment trends over time, the $\mathrm{X}^{2}$ was 12.549 and the probability was 0.005 . Thus, the result was statistically significant (Table 3 ). 


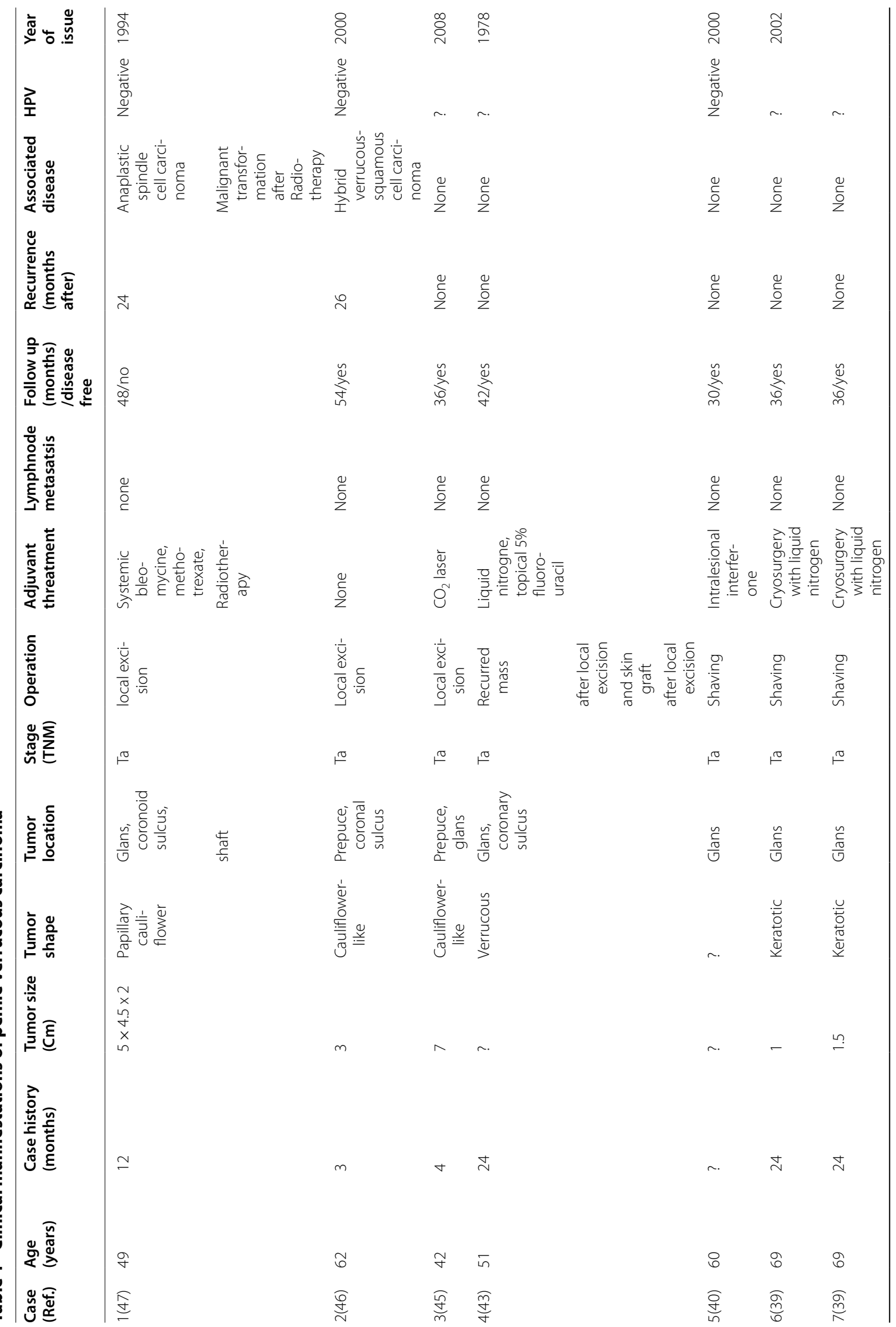




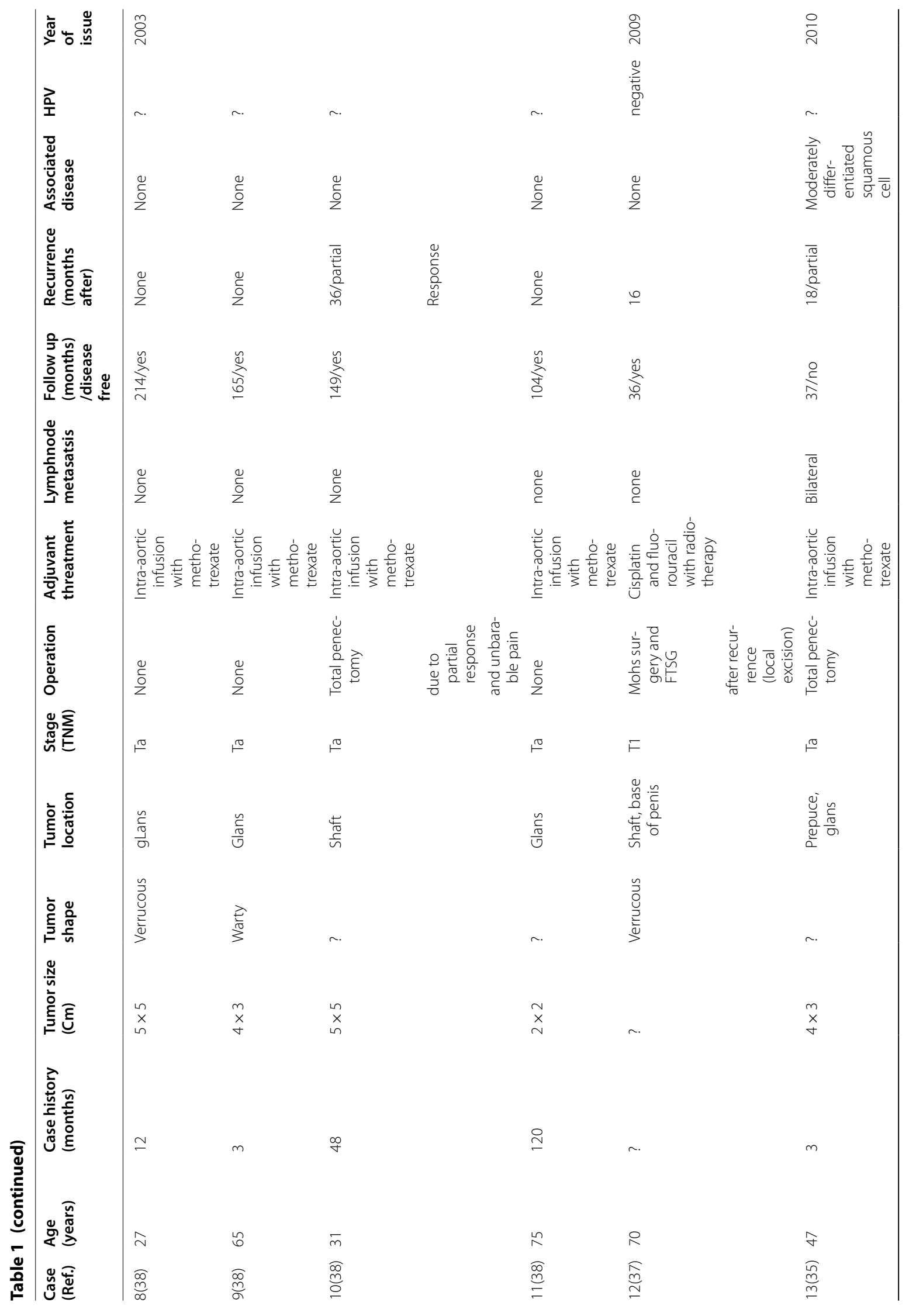




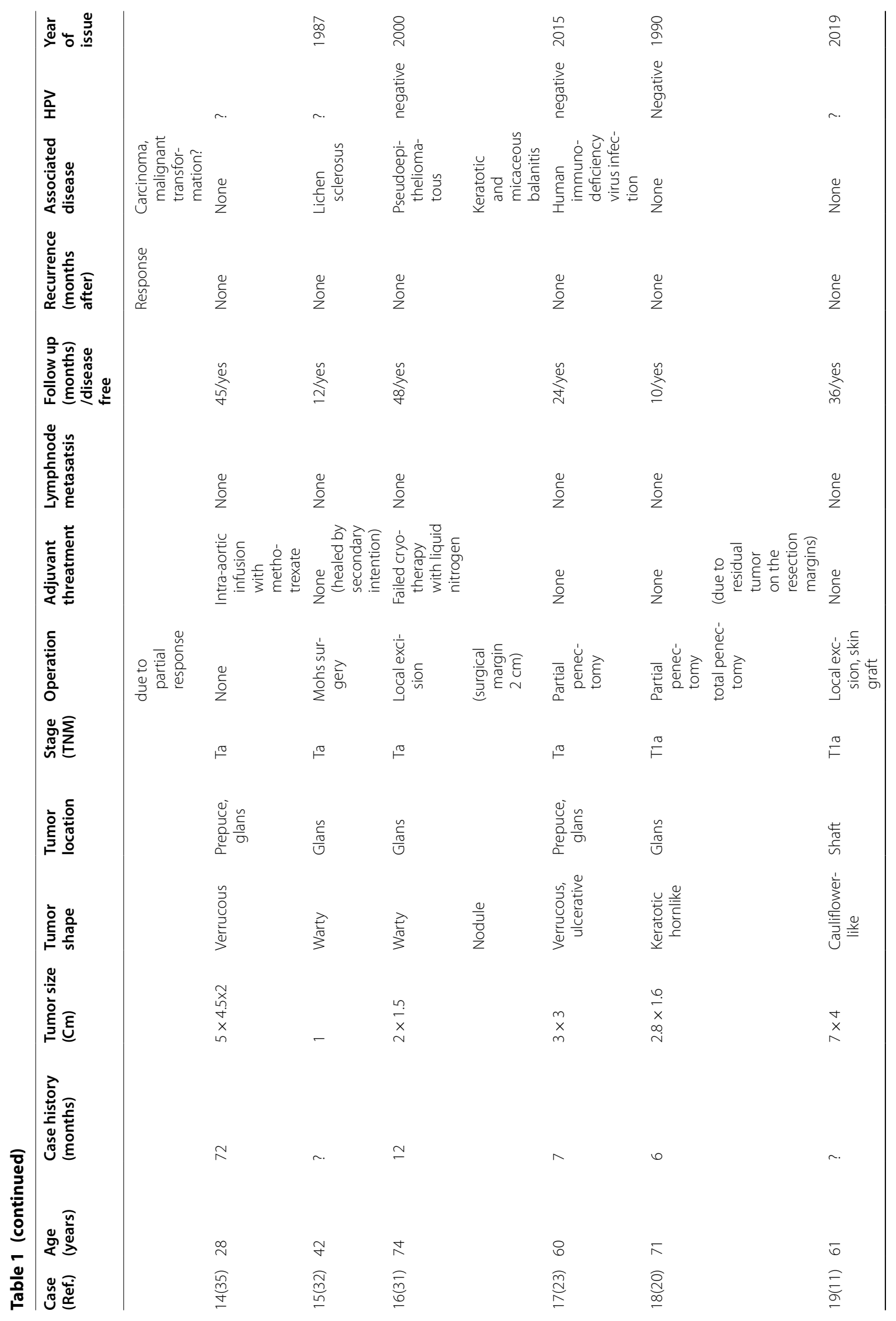




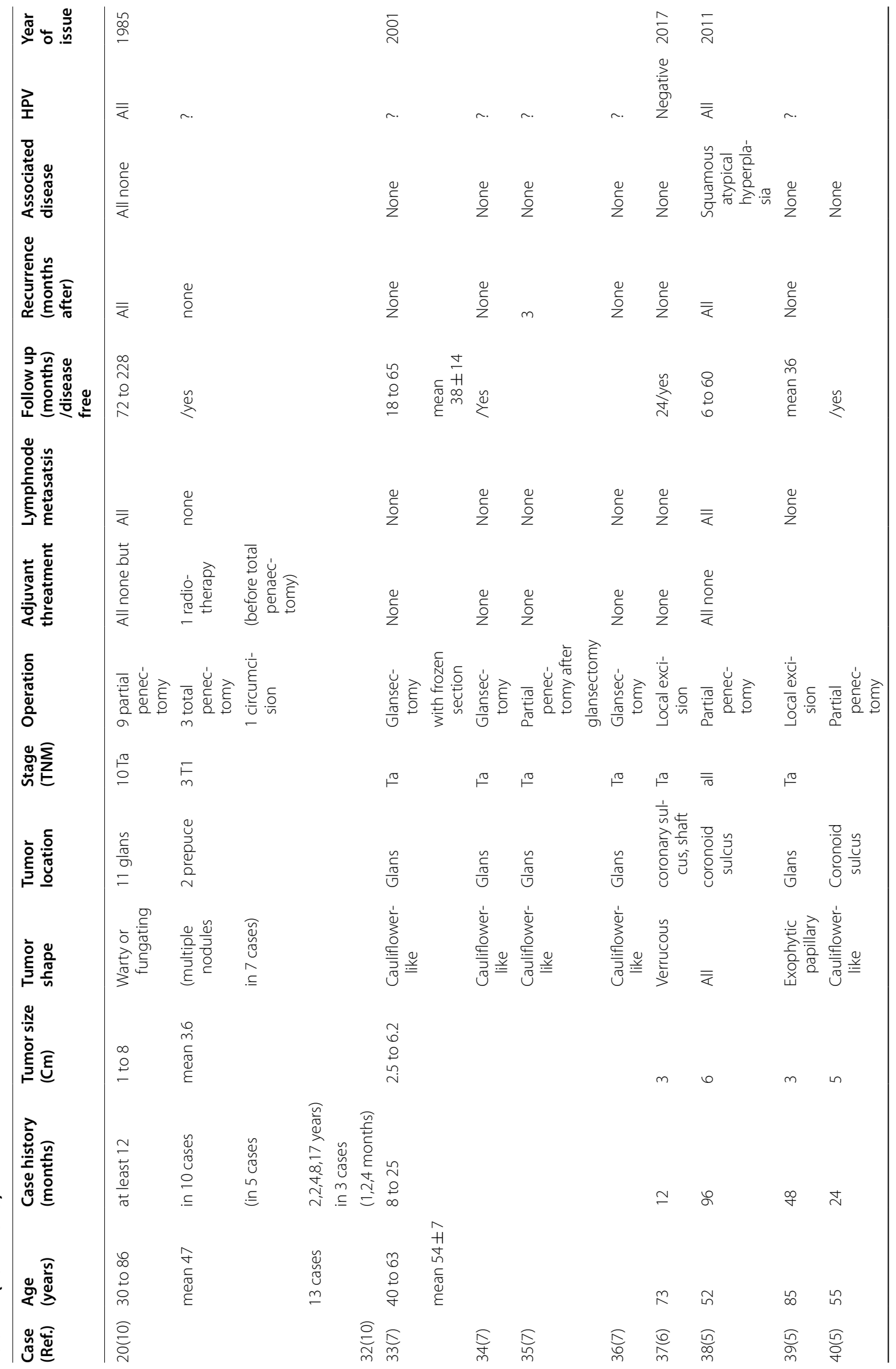




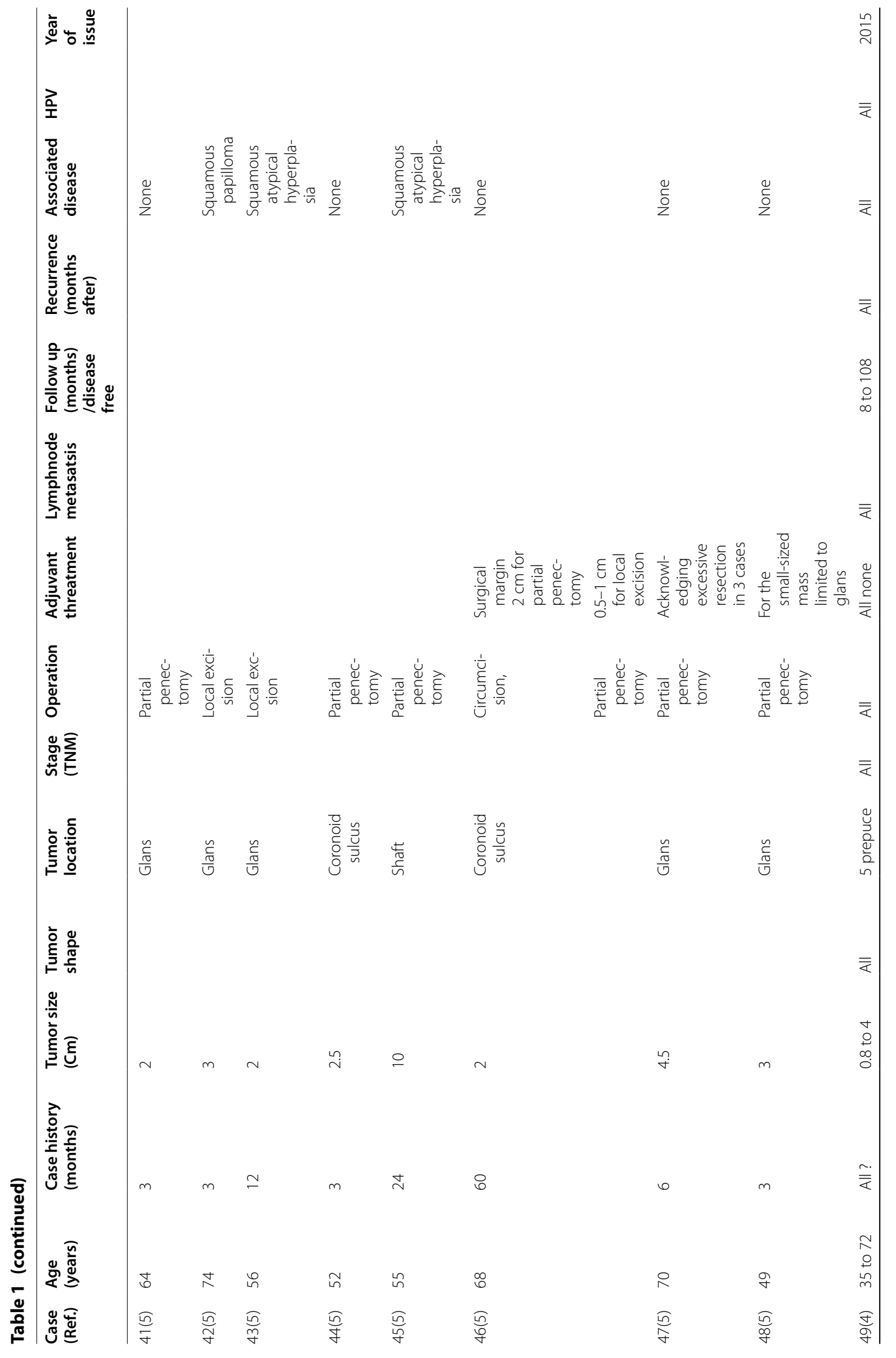




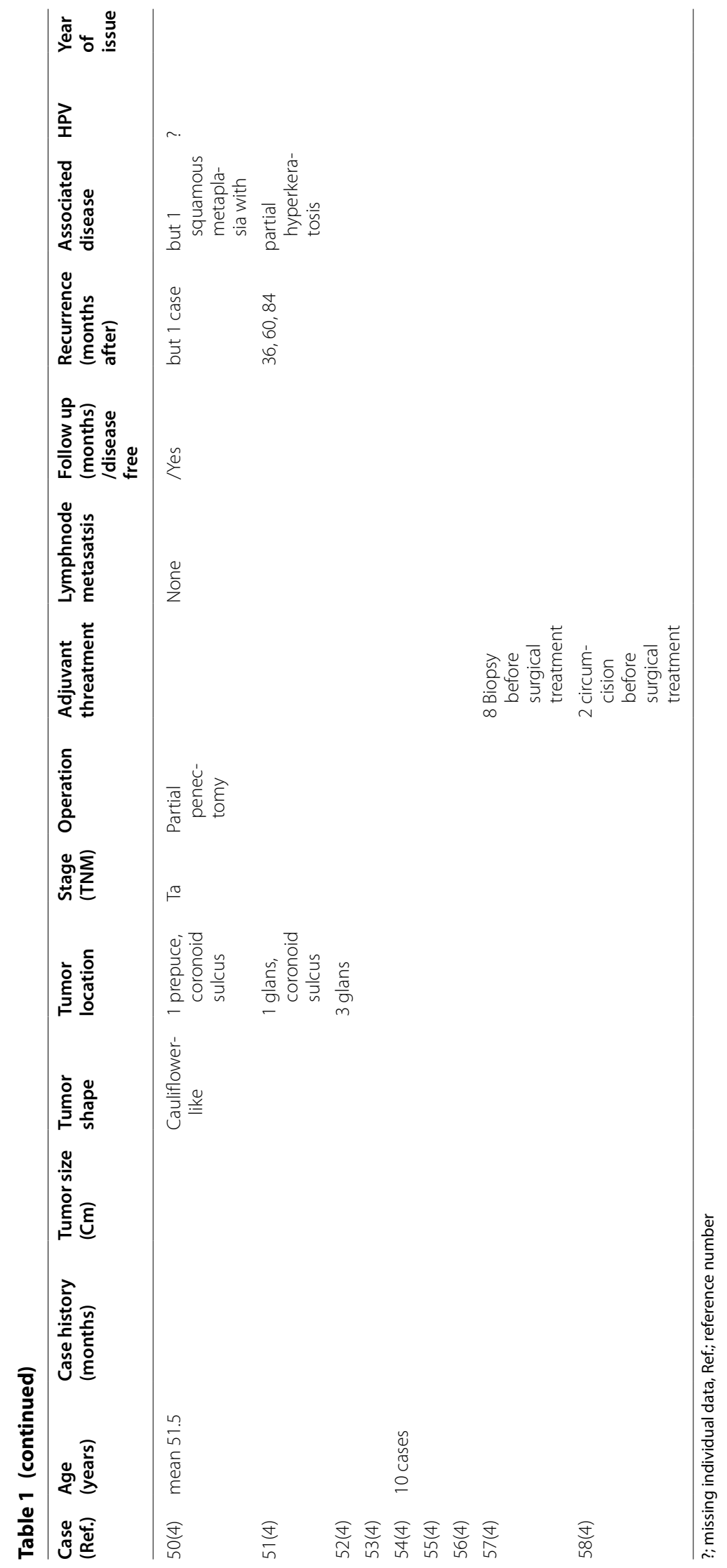


Table 2 Cumulative data of clinical presentations and treatments

\begin{tabular}{|c|c|}
\hline Total cases & 58 \\
\hline Age (years) & $28-86$ \\
\hline Case History (months) & $1-204$ \\
\hline Size $(\mathrm{Cm})$ & $0.8-10$ \\
\hline \multicolumn{2}{|l|}{ Tumor shape } \\
\hline $\begin{array}{l}\text { Papillary cauliflower } \\
\text { Keratotic hornlike } \\
\text { Warty verrucous } \\
\text { Unknown }\end{array}$ & $\begin{array}{l}30 \\
3 \\
21 \\
4\end{array}$ \\
\hline \multicolumn{2}{|l|}{ Location (cases) } \\
\hline $\begin{array}{l}\text { Glans } \\
\text { Coronoid sulcus } \\
\text { Shaft } \\
\text { Prepuce } \\
\text { Prepuce and glans } \\
\text { Glans and coronoid sulcus and shaft } \\
\text { Prepuce and coronoid sulcus } \\
\text { Glans and coronoid sulcus } \\
\text { Coronoid sulcus and shaft } \\
\text { Coronoid sulcus involvement }\end{array}$ & $\begin{array}{l}33 \\
4 \\
4 \\
7 \\
4 \\
1 \\
2 \\
2 \\
1 \\
10\end{array}$ \\
\hline \multicolumn{2}{|l|}{ Stage (cases) } \\
\hline $\begin{array}{l}\mathrm{Ta} \\
\mathrm{T} 1\end{array}$ & $\begin{array}{l}52 \\
6\end{array}$ \\
\hline \multicolumn{2}{|l|}{ Treatment (cases) } \\
\hline $\begin{array}{l}\text { No surgery } \\
\text { Local excision } \\
\text { Shaving } \\
\text { Mohs surgery } \\
\text { Circumcision } \\
\text { Glansectomy } \\
\text { Partial penectomy } \\
\text { Total penectomy }\end{array}$ & $\begin{array}{l}4 \\
10 \\
3 \\
2 \\
1 \\
3 \\
29 \\
6\end{array}$ \\
\hline \multicolumn{2}{|l|}{ Adjuvant treatment (cases) } \\
\hline $\begin{array}{l}\text { Radiotherapy } \\
\text { Chemotherapy } \\
\text { Chemoradiotherapy } \\
\text { Local therapy ( } \mathrm{CO}_{2} \text { laser, cryotherapy, intralesional interferon, } \\
\text { and topical fluorouracil) }\end{array}$ & $\begin{array}{l}1 \\
6 \\
2 \\
6\end{array}$ \\
\hline Lymphnode metastasis (cases) & 1 \\
\hline Follow up period (months) & $6-228$ \\
\hline Recurrence (cases) & 7 \\
\hline Disease free (cases) & 56 \\
\hline Surgical margin $(\mathrm{Cm})$ & $0.3-2$ \\
\hline \multicolumn{2}{|l|}{ Cases following the year of issue (cases) } \\
\hline $\begin{array}{l}1970 s \\
1980 s \\
1990 s \\
2000 s \\
2010 s\end{array}$ & $\begin{array}{l}1 \\
14 \\
2 \\
15 \\
26\end{array}$ \\
\hline
\end{tabular}

According to the regression analysis of age, case history, tumor size, tumor shape, tumor location, tumor stage, adjuvant treatment, tumor recurrence, and treatment trends over time did not appear to have a significant negative or positive effect (data not shown).
In summary, the associations between tumor location and treatment method and tumor depth and treatment method were not statistically significant. Adjuvant therapy tended to be performed alone or with local excision preventing a penectomy or glansectomy. Partial penectomy cases (aggressive treatment group) were predominantly reported in the 2010s. No intergroup differences were seen in clinical results. Therefore, our hypothesis that aggressive treatment is more effective was rejected.

\section{Discussion}

Some studies have reported that PVC is observed in approximately $2.4-24 \%$ of all penile cancers and $20 \%$ of verruciform lesions of the penis; PVC is also observed in patients with Buschke-Löwenstein, warty carcinoma, and papillary SCC [1-3]. Several cases have been reported during the past 2-3 decades among many countries due to its rarity $[10,48-51]$. PVC primarily occurs in the glans penis, and phimosis and redundant prepuce are 2 of its important causes [2, 52]. Lichen sclerosus and pseudoepitheliomatous, keratotic, and micaceous balanitis are other possible causes [31-33, 53]. Local squamous epithelial hyperplasia and hyperkeratosis may be important in the development of PVC [54, 55]. Clinically, they do not cause significant pain, but they grow slowly and uninhibited, sometimes invading the shaft over the glans. In most cases, the patients present with a slow-growing mass with multiple papillary lesions [4-6].

Biopsy and HPV PCR tests are basic diagnostic tools for differentiating PVC from HPV-related tumors. Increased immunohistochemical expression of markers such as Mdm2 and Ki67 and low expression of Bcl-2 may be useful for the detection of PVC [56-58]. Microscopically, the hematoxylin- and eosin-stained sections shows extension of the epithelium downward into the underlying tissues in a bulbous or drumstick process, while the tumor exhibits clear boundaries and rich lymphocytic infiltration into the surrounding mesenchyme [4-6].

To avoid misdiagnosis, repeated deeper biopsies are recommended that include the basement membrane of the papillomatous tumor, especially in cases in which PVC is highly suspected. However, because the gross morphology of PVC is very similar to that of condyloma acuminatum, it can be difficult to identify. HPV is known to be closely associated with penile cancer and condyloma acuminatum in most cases [8]. In contrast, in all PVC cases, the pathogenesis is not associated with HPV infection [3, 59-61]. Thus, an HPV-negative status may be the key in the differential diagnosis of PVC. In our study, the differential diagnosis from condyloma acuminatum was confirmed in only 8 cases. We assume that diagnostic biopsy played a decisive role since HPV infection status was unknown. 
Table 3 Cross analysis (chi-square) with Fisher's exact test

\begin{tabular}{|c|c|c|c|c|c|c|}
\hline & & & \multicolumn{2}{|l|}{ Operation } & \multirow[t]{2}{*}{ Total } & \multirow{2}{*}{$\begin{array}{l}x^{2} \\
(p)\end{array}$} \\
\hline & & & $\begin{array}{l}\text { Less aggressive } \\
\text { treatment }\end{array}$ & $\begin{array}{l}\text { Aggressive } \\
\text { treatment }\end{array}$ & & \\
\hline \multirow[t]{4}{*}{ Tumor location } & \multirow[t]{2}{*}{ Glans } & Case & 11 & 22 & 33 & \multirow[t]{4}{*}{$\begin{array}{l}2.532 \\
(.686)\end{array}$} \\
\hline & & $\%$ & $55.0 \%$ & $57.9 \%$ & $56.9 \%$ & \\
\hline & \multirow{2}{*}{$\begin{array}{l}\text { Coronoid } \\
\text { sulcus involvement }\end{array}$} & Case & 4 & 6 & 10 & \\
\hline & & $\%$ & $20.0 \%$ & $15.8 \%$ & $17.2 \%$ & \\
\hline \multirow[t]{4}{*}{ Stage } & \multirow[t]{2}{*}{$\mathrm{Ta}$} & Case & 17 & 35 & 52 & \multirow{4}{*}{$\begin{array}{l}.713 \\
(.405)\end{array}$} \\
\hline & & $\%$ & $85.0 \%$ & $92.1 \%$ & $89.7 \%$ & \\
\hline & \multirow[t]{2}{*}{$\mathrm{T} 1$} & Case & 3 & 3 & 6 & \\
\hline & & $\%$ & $15.0 \%$ & $7.9 \%$ & $10.3 \%$ & \\
\hline \multirow[t]{10}{*}{ Adjuvant treatment } & \multirow[t]{2}{*}{ none } & Case & 8 & 35 & 43 & \multirow{10}{*}{$\begin{array}{l}21.926^{* *} \\
(.000)\end{array}$} \\
\hline & & $\%$ & $40.0 \%$ & $92.1 \%$ & $74.1 \%$ & \\
\hline & \multirow[t]{2}{*}{ Radiotherapy } & Case & 0 & 1 & 1 & \\
\hline & & $\%$ & $0.0 \%$ & $2.6 \%$ & $1.7 \%$ & \\
\hline & \multirow[t]{2}{*}{ Chemotherapy } & Case & 4 & 2 & 6 & \\
\hline & & $\%$ & $20.0 \%$ & $5.3 \%$ & $10.3 \%$ & \\
\hline & \multirow[t]{2}{*}{ Chemoradiotherapy } & Case & 2 & 0 & 2 & \\
\hline & & $\%$ & $10.0 \%$ & $0.0 \%$ & $3.4 \%$ & \\
\hline & \multirow[t]{2}{*}{ Local therapy } & Case & 6 & 0 & 6 & \\
\hline & & $\%$ & $30.0 \%$ & $0.0 \%$ & $10.3 \%$ & \\
\hline \multirow[t]{4}{*}{ Recurrence } & \multirow[t]{2}{*}{ No } & Case & 17 & 34 & 51 & \multirow{4}{*}{$\begin{array}{l}.247 \\
(.619)\end{array}$} \\
\hline & & $\%$ & $85.0 \%$ & $89.5 \%$ & $87.9 \%$ & \\
\hline & \multirow[t]{2}{*}{ Yes } & Case & 3 & 4 & 7 & \\
\hline & & $\%$ & $15.0 \%$ & $10.5 \%$ & $12.1 \%$ & \\
\hline \multirow{10}{*}{$\begin{array}{l}\text { Treatment trends over time fol- } \\
\text { lowing the year of issue }\end{array}$} & \multirow[t]{2}{*}{$1970 \mathrm{~s}$} & Case & 1 & 0 & 1 & \multirow{10}{*}{$\begin{array}{l}12.549^{* *} \\
(.005)\end{array}$} \\
\hline & & $\%$ & $5.0 \%$ & $0.0 \%$ & $1.7 \%$ & \\
\hline & \multirow[t]{2}{*}{$1980 \mathrm{~s}$} & Case & 2 & 12 & 14 & \\
\hline & & $\%$ & $10.0 \%$ & $31.6 \%$ & $24.1 \%$ & \\
\hline & \multirow[t]{2}{*}{ 1990s } & Case & 1 & 1 & 2 & \\
\hline & & $\%$ & $5.0 \%$ & $2.6 \%$ & $3.4 \%$ & \\
\hline & \multirow[t]{2}{*}{$2000 \mathrm{~s}$} & Case & 10 & 5 & 15 & \\
\hline & & $\%$ & $50.0 \%$ & $13.2 \%$ & $25.9 \%$ & \\
\hline & \multirow[t]{2}{*}{$2010 \mathrm{~s}$} & Case & 6 & 20 & 26 & \\
\hline & & $\%$ & $30.0 \%$ & $52.6 \%$ & $44.8 \%$ & \\
\hline
\end{tabular}

${ }^{*} p<0.05,{ }^{* *} p<0.01$

Surgical treatments reported in other studies focused on aggressive treatments, including glansectomy and partial or total penectomy with a 4-20-mm surgical margin $[4,5,7,8]$. Partial penectomy with a 2 -cm margin has traditionally been the suggested treatment for tumors involving the glans penis, with total penectomy being indicated when the tumor involves a larger portion of the penile shaft [49].

However, since PVC has a relatively rare incidence and is termed carcinoma despite its favorable behavior, surgeons often lack of experience treating such cases and decide to unnecessarily remove part or all of the penis.
Moreover, wide excision was commonly performed for relatively small masses $(\leq 3 \mathrm{~cm})$ [5]. However, since the 1980s, local excision has been advised to preserve the penis [4-6],15,17. Mohs surgery was adopted in cases of PVC showing favorable behavior [15, 62]. The authors agree that local excision should be the first choice of treatment because of the favorable biological behavior of PVC. Treatments have been suggested according to 2 general concepts: penectomy is mandatory because PVC is malignant; and less aggressive treatment as local excision is sufficient because the biological behavior of PVC resembles that of a benign tumor. 
This review revealed that the glans was the area most often involved in cases of PVC. We expected that distal and local lesions would be treated less aggressively. However, as a result, tumor location did not affect treatment aggressiveness. Interestingly, the coronoid sulcus involvement suggests that, in the absence of a dartos layer, penile carcinoma would more rapidly infiltrate the penile fascia, a known low-resistance pathway for local spread; thus, clinicians would expect a higher risk of tumor recurrence and inguinal involvement as well as a worse outcome. Thus, we expected that coronoid sulcus involvement would require more aggressive treatment. However, our results demonstrated 11 cases in the less aggressive treatment group versus 22 cases in the aggressive treatment group, respectively. Although there were more cases in the latter than the former group, the intergroup difference was insignificant.

Regarding tumor depth, PVC is defined as a superficial stage Ta lesion by the 2016 Tumor Node Metastasis (TNM) classification, a so-called non-invasive verrucous carcinoma. Although no statistically significant intergroup difference was noted, aggressive treatments were more often applied than less aggressive treatments for superficial lesions. However, 20 cases of the less aggressive treatment group showed good clinical results. Stage $\mathrm{T} 1$ tumors were seen, even in cases of deeper lesions. This means that less aggressive treatments with careful follow-up of stage T1 tumors can also result in good post-treatment results.

Even if a case of PVC is malignant, it may present as a benign tumor. Thus, to preserve functional and cosmetic results, we recommend that local excision with minimal surgical margins followed by careful observation be the first-line choice of treatment, especially for tumors measuring $<3 \mathrm{~cm}$ and classified as stage $\mathrm{T} 1$. In other conditions, the tumor should be considered not PVC and the excision should be widened. In our study, we excluded tumor staging beyond T2. Stage T2 penile cancers are different from PVC and defined as invasive cancers such as squamous cell carcinoma and others with bad prognosis. In these cases, aggressive treatment is recommended.

Regarding adjuvant therapy, preventive inguinal lymphadenectomy was hardly used because of rarity of evident lesions $[4,5,9,34,35,63,64]$. Conservative systemic chemotherapy without surgery was reported [35, 38]. Other adjuvant therapies for the verrucous lesion have been introduced, such as topical aminolevulinic acidphotodynamic therapy; topical, systemic, or intralesional interferon; cryotherapy; laser therapy; and radiation [35-45, 65, 66]. Our results demonstrated that adjuvant treatments were more predominantly applied when less aggressive treatment was administered. This finding supports that conservative surgery could be the first choice of treatment. However, the 4 cases treated with intralesional interferon and 1 case of cryotherapy with good clinical results could not be evaluated due to the absence of information on tumor stage [25, 41, 42].

This literature review revealed that inguinal lymphadenectomy was performed in certain patients; however, no evident lesions were found in such cases $[4,5,9,34$, $35,63,64]$. The 1 case of lymph node metastasis reported was suspected to be a combined lesion with moderately differentiated SCC [35]. Thus, we agree that inguinal lymphadenectomy is not an appropriate prophylactic treatment. For lymphadenopathy, treatment with antiinflammatory drugs may be the treatment of choice, followed by a lymph node biopsy as needed. Thus, if a case of PVC is confirmed by biopsy and no signs of inguinal lymphadenopathy are seen on physical examination, further workups such as computed tomography or ultrasonography could be postponed initially, and high-end MRI saved for later and then used if needed to investigate tumor depth [67].

As for tumor behavior, complicated microlesions of invasive SCC, a certain number of which eventually progressed to other invasive types, have been observed in $<30 \%$ of the reported cases of PVC $[46,68]$. There was one case of recurrent SCC after anaplastic transformation following radiation therapy [47]. Therefore, close follow-up for the early detection of any sign of recurrence requiring additional resection is essential after a less aggressive treatment, such as local excision. In our study, all but 2 cases achieved tumor-free status during long follow-up periods despite 7 cases of recurrence. Regarding those 2 cases, 1 was suspected as malignant transformation after radiotherapy to anaplastic spindle cell carcinoma [47] and the other was the previously mentioned lymph node metastasis case that eventually failed treatment and required total penectomy due to partial response after chemotherapy [35].

Despite the favorable clinical behavior of PVC and the many studies emphasizing less aggressive treatments, the use of aggressive treatment was predominantly reported in the 2010s. However, we do not think that this reflects the recent treatment trends because the timing of the reported treatment does not represent the actual clinical practice at the time.

However, information is still lacking about the association between treatment and tumor condition, evidence of which could lead us to define an appropriate guideline. Due to the limitations of a literature review, controllable factors were often undetermined. Thus, we recommend that future studies always include a unified scale for multiple factors including tumor condition and functional outcome. This mission will require long discussions and consensus of many experts. Despite this limitation, we believe that our 
findings are meaningful since this is the first review of diagnostic and treatment trends of PVC, a rare condition.

\section{Conclusion}

The review performed here revealed that PVC tends not to recur or metastasize after resection but that surgical treatment tends to remove too much tissue. However, in most cases of local excision, the wound heals well and local recurrence rarely occurs. Therefore, considering the ability of local excision with minimal surgical margins to spare the functional and cosmetic aspects of the penile shaft and glans penis, we recommend it as the first-line choice of treatment with observation, especially for tumors measuring $<3 \mathrm{~cm}$ and classified as stage T1 according to the 2016 tumor node metastasis clinical and pathological classification for penile cancer.

\section{Abbreviations}

HPV: Human papilloma virus; MRI: Magnetic resonance imaging; PCR: Polymerase chain reaction; PVC: Penile verruca carcinoma; SCC: Squamous cell carcinoma; TNM: Tumor node metastasis.

\section{Acknowledgements}

We would like to thank Editage (www.editage.co.kr) for English language editing.

\section{Authors' contributions}

HK have made substantial contributions to the conception of the work; SH, SK, $\mathrm{HYK}$ and $\mathrm{HC}$ have made substantial contributions to the acquisition and analysis of data; DJ have made substantial contributions to the design of the work and the interpretation of data and have drafted the work and substantively revised it. All authors have read and approved the final manuscript.

\section{Funding}

None.

\section{Availability of data and materials}

Not applicable.

Ethics approval and consent to participate

Not applicable.

\section{Consent to publish}

Not applicable.

\section{Competing interests}

The authors declare no conflicts of interest.

\section{Author details}

${ }^{1}$ Department of Plastic and Reconstructive Surgery, Konkuk University School of Medicine, Chungju, Republic of Korea. ${ }^{2}$ Department of Anesthesiology and Pain Medicine, Konkuk University School of Medicine, Chungju, Republic of Korea. ${ }^{3}$ Department of Urology, Konkuk University School of Medicine, Gukwon-daero 82, 27376 Chungju, Chungbuk, Republic of Korea.

Received: 3 January 2020 Accepted: 21 December 2020

Published online: 29 January 2021

\section{References}

1. Chaux A, Velazquez EF, Algaba F, et al. Developments in the pathology of penile squamous cell carcinoma. Urology. 2010;76(2 Suppl 1):S7-14.
2. Schwartz RA. Verrucous carcinoma of the skin and mucosa. J Am Acad Dermatol. 1995;32(1):1-21.

3. Stankiewicz E, Kudahetti SC, Prowse DM, et al. HPV infection and immunochemical detection of cell-cycle markers in verrucous carcinoma of the penis. Mod Pathol. 2009;22(9):1160-8.

4. Li F, Xu Y, Wang H, et al. Diagnosis and treatment of penile verrucous carcinoma. Oncol Lett. 2015:9(4):1687-90.

5. Chuanyu S, Ke X, Jie Z, et al. Surgical treatment for 11 cases of penile verrucous carcinoma. Ann Dermatol. 2011;23(Suppl 3):S346-349.

6. Dong In Jo, Hong Sup Kim, et al. Local excision for the treatment of penile verrucous carcinoma. Urology Case Reports 2017;13:16-18.

7. Hatzichristou DG, Apostolidis A, Tzortzis V, et al. Glansectomy: an altemative surgical treatment for Buschke-Löwenstein tumors of the penis. Urology. 2001;57:966-9.

8. Chen GX, Li ZH, Zhang XS, Ding DG, Zhu XB, Chen X. Clinicopathological features and management of penile verrucous carcinoma. Zhonghua Nan Ke Xue. 2018;24(1):62-6.

9. Bañón Pérez V, Nicolás Torralba JA, Valdelvira Nadal P, Martínez Barba E, Server Pastor G, López Cubillana P, Prieto González A, Pérez AM. Penile verrucous carcinoma. Arch Esp Urol. 1999:52(9):937-40.

10. Johnson DE, Lo RK, Srigley J, Ayala AG. Verrucous carcinoma of the penis. J Urol. 1985;133(2):216-8.

11. Philippou P, Kitsios C, Miliatou M, Poullou C, Konstantinou P. Organsparing surgery for a giant verrucous carcinoma of the penile shaft: a case report and review of the literature. Case Rep Urol. 2019;2019:1537379. https://doi.org/10.1155/2019/1537379.

12. Wang ZL, Ou MR, Sun XL, Wang XF, Zhang JF, Sun LJ, Zhao P, Ji XR. Diagnosis and treatment of penile verrucous carcinoma: a report of 4 cases. Zhonghua Nan Ke Xue. 2007;13(6):527-30.

13. Venkov G. Verrucous carcinoma of the penis. Khirurgiia (Sofiia). 2003:59(6):22-4.

14. Sánchez Zalabardo D, Toledo Santana G, Arocena García-Tapia J, Sanz Pérez G, Diez-Caballero Alonso F, Martín-Marquina Aspiunza A, Rosell CD. Verrucous carcinoma of the penis: report of 2 cases. Arch Esp Urol. 2001;54(1):76-9.

15. Muro Vidaurre I, Hernáez Manrique I, Sanz Jaka JP, Rekarte Barriola JA, Lluch CA. Verrucous carcinoma of the penis: local excision with the Mohs micrographic technique. Arch Esp Urol. 1996;49(9):959-64.

16. Llarena Ibarguren R, Pérez García A, Zabala Egurrola JA, Arruza EA. Verrucous carcinoma of the penis: apropos of 2 cases. Arch Esp Urol. 1989;42(1):30-2.

17. Graziotti P, Maio G, Aragona F, Dal Bianco M, Cisternino A, Dante S. Verrucous carcinoma of the penis. 2 cases and review of the literature. J Chir (Paris). 1988;125(5):364-366.

18. Yaman I, Bozdag AD, Derici H, Tansug T, Reyhan E. Verrucous carcinoma arising in a giant condyloma acuminata (Buschkelowenstein Tumour): ten-year follow-up. Ann Acad Med Singapore. 2011;40(2):104-5.

19. Zhu JW, Luo D, Li CR, Lu Y, Ji X, Zhu J, Ming YL, Shen CH. A case of penile verrucous carcinoma associated with cutaneous horn. Clin Exp Dermatol. 2007;32(2):213-4.

20. Yeager JK, Findlay RF, McAleer IM. Penile verrucous carcinoma. Arch Dermatol. 1990;126(9):1208-10.

21. Castillo Jimeno JM, Queron Nasarre I, Cea Rey SA, Paredero Paredero S, Jaso López AC, Córdoba A. Verrucous carcinoma of the penis: report of two cases. Arch Esp Urol. 1996;49(7):757-60.

22. Beddouche A, Kallat A. Penile verrucous carcinoma. Pan Afr Med J. 2016:24:188.

23. Noronha TM, Girisha BS, Bhat SP, Christy CM, Handattu S, Fernandes MS. A rare case of verrucous carcinoma of penis in an human immunodeficiency virus- infected patient. Indian J Sex Transm Dis AIDS. 2015;36(2):192-4.

24. Fujimoto N, Nakanishi G, Ushida H, Okada Y, Tanaka R, Fujimoto W, Jo $Y$, Hara R, Tanaka T. Penile verrucous carcinoma arising in HPV-negative condylomatous papules. Eur J Dermatol. 2011;21(3):436-8.

25. Kanik $A B$, Lee J, Wax F, Bhawan J. Penile verrucous carcinoma in a 37-year-old circumcised man. J Am Acad Dermatol. 1997;37(2 Pt 2):329-31.

26. Vesga Molina F, Llarena Ibarguren $R$, Acha Pérez M, Albisú Tristán A, Blasco de Villalonga M, Arruza Echevarría A, Pertusa Peña C. Verrucous carcinoma of the penis: our caseload. Arch Esp Urol. 1993;46(1):23-25. 
27. Rossi M, Giustina A, Tonetti F, Gorini P, Mina A, Dutto C, Nobili U. Verrucous carcinoma of the penis. A case report and review of the literature. Minerva Chir. 1991;46(18):999-1002.

28. Castiñeiras Fernández J, López Múñoz A, Cabello Torres P, Vilches TJ. Verrucous carcinoma of the penis. Actas Urol Esp. 1991;15(2):169-72.

29. Shah PJ, Abrams PH, Gaches CG, Ashken MH, McCann BG. Verrucous carcinoma of the penis or Buschke-Löwenstein tumour. Eur Urol. 1981;7(2):78-80.

30. Smith $\mathrm{RB}$, Young $\mathrm{HH}$ 2nd, Chaffey BT. Verrucous carcinoma of the penis: report of a case and review. Br J Urol. 1969;41(3):327-31.

31. Child FJ, Kim BK, Ganesan R, Southern SA, Herrington CS, Calonje E. Verrucous carcinoma arising in pseudoepitheliomatous keratotic and micaceous balanitis, without evidence of human papillomavirus. $\mathrm{Br} J$ Dermatol. 2000;143(1):183-7.

32. Weber P, Rabinovitz H, Garland L. Verrucous carcinoma in penile lichen sclerosus et atrophicus. J Dermatol Surg Oncol. 1987;13(5):529-32.

33. Barbagli G, Palminteri E, Mirri F, Guazzoni G, Turini D, Lazzeri M. Penile carcinoma in patients with genital lichen sclerosus: a multicenter survey. J Urol. 2006;175(4):1359-63.

34. Seixas AL, Ornellas AA, Marota A, et al. Verrucous carcinoma of the penis: retrospective analysis of 32 cases. J Urol. 1994;152:1476-9.

35. Sheen MC, Sheu HM, Jang MY, et al. Advanced penile verrucous carcinoma treated with intra-aoritc infusion chemotherapy. J Urol. 2010;183(5):1830-5.

36. He X, Zhang J, Tan L, Wang W, Song Y, Wang H, Zhang X, Kou H1, Lu Y. Treatment of verrucous carcinoma in penis with topical aminolevulinic acid photodynamic therapy: An effective and safe treatment method. Photodiagnosis Photodyn Ther. 2018;24:232-236.

37. Eliason M, Bowen G, Bowen A, Hazard L, Samlowski W. Primary treatment of verrucous carcinoma of the penis with fluorouracil, cis-diamino-dichloro-platinum and radiation therapy. Arch Dermatol. 2009;145(8):950-2.

38. Sheen MC, Sheu HM, Huang CH, Wang YW, Chai CY, Wu CF. Penile verrucous carcinoma successfully treated by intra-aortic infusion with methotrexate. Urology. 2003;61(6):1216-20.

39. Michelman FA, Filho AC, Moraes AM. Verrucous carcinoma of the penis treated with cryosurgery. J Urol. 2002;168(3):1096-7.

40. Gómez De La Fuente E, Castaño Suarez E, Vanaclocha Sebastian F, Rodriguez-Peralto JL, Iglesias Díez L. Verrucous carcinoma of the penis completely cured with shaving and intralesional interferon. Dermatology. 2000;200(2):152

41. Maiche AG, Pyrhonen S. Verrucous carcinoma of the penis: three cases treated with interferon-alpha. Br J Urol. 1997;79(3):481-3.

42. Pyrhönen S, Maiche AG, Mäntyjärvi R. Verrucous carcinoma of the penis successfully treated with interferon. Br J Urol. 1991;68(1):102-4.

43. Carson TE. Verrucous carcinoma of the penis. Successful treatment with cryosurgery and topical fluorouracil therapy. Arch Dermatol. 1978;114(10):1546-1547.

44. IIkay AK, Chodak GW, Vogelzang NJ, Gerber GS. Buschke-Lowenstein tumor: therapeutic options including systemic chemotherapy. Urology. 1993;42(5):599-602

45. Martin JM, Molina I, Monteagudo C, Marti N, Lopez V, Jorda E. BuschkeLowenstein tumor. J Dermatol Case Rep. 2008:2(4):60-2.

46. Kato N, Onozuka T, Yasukawa K, Kimura K, Sasaki K. Penile hybrid verrucous-squamous carcinoma associated with a superficial inguinal lymph node metastasis. Am J Dermatopathol. 2000;22(4):339-43.

47. Fukunaga M, Yokoi K, Miyazawa Y, Harada T, Ushigome S. Penile verrucous carcinoma with anaplastic transformation following radiotherapy. A case report with human papillomavirus typing and flow cytometric DNA studies. Am J Surg Pathol. 1994;18(5):501-505.

48. Korczak D, Siegel Y, Lindner A. Verrucous carcinoma of the penis. Harefuah. 1989;117(12):436-7.

49. Zheng FF, Liang YY, Guo YS, Dai YP, Zheng KL. Diagnosis and therapy for penile cancer: a report of 46 cases with literature review. Ai Zheng 2008;27(9):962-5.
50. Heyns CF, van Vollenhoven P, Steenkamp JW, Allen FJ. Cancer of the penis-a review of 50 patients. S Afr J Surg. 1997;35(3):120-4.

51. Bañón Pérez VJ, Nicolás Torralba JA, Valdelvira Nadal P, Server Pastor G, Martínez Barba E, Gómez Gómez G, Prieto González A, López Cubillana P, Pérez AM. Malignant neoplasms of the penis. Actas Urol Esp. 2000;24(8):652-8

52. Chen MF, Chen WC, Wu CT, et al. Contemporary management of penile cancer including surgery and adjuvant radiotherapy: an experience in Taiwan. World J Urol. 2004:22:60-6.

53. Alvarez Alvarez C, Meijide Rico F, Rodríguez González L, Antón Badiola I, Zungri Telo E, Antonio Ortiz-Rey J. Verrucous carcinoma of the penis arising from a lichen planus. A true preneoplastic lesion? Actas Urol Esp. 2006:30(1):90-92.

54. Chaux A, Cubilla AL. The role of human papillomavirus infection in the pathogenesis of penile squamous cell carcinomas. Semin Diagn Pathol. 2012;29:67-71.

55. Velazquez EF, Chaux A, Cubilla AL. Histologic classification of penile intraepithelial neoplasia. Semin Diagn Pathol. 2012;29:96-102.

56. Ouban A1, Dellis J, Salup R, Morgan M.: Immunohistochemical expression of Mdm2 and p53 in penile verrucous carcinoma. Ann Clin Lab Sci. 2003 Winter;33(1):101-106

57. Medina Pérez M, Valero Puerta J, Martínez Igarzabal MJ. Verrucous carcinoma of the penis with intense basal expression of Ki 67. Arch Esp Urol. 1999;52(9):983-5.

58. Saeed S, Keehn CA, Khalil FK, Morgan MB. Immunohistochemical expression of Bax and Bcl-2 in penile carcinoma. Ann Clin Lab Sci. 2005 Winter;35(1):91-96.

59. Masih AS, Stoler MH, Farrow GM, Wooldridge TN, Johansson SL. Penile verrucous carcinoma: a clinicopathologic, human papillomavirus typing and flow cytometric analysis. Mod Pathol. 1992;5(1):48-55.

60. Chan KW, Lam KY, Chan AC, Lau P, Srivastava G. Prevalence of human papillomavirus types 16 and 18 in penile carcinoma: a study of 41 cases using PCR. J Clin Pathol. 1994;47(9):823-6.

61. KIMBERLY L. BRADY, MD, MARY GAIL MERCURIO, MD, AND MARC D. BROWN, MD. Malignant Tumors of the Penis. Dermatol Surg. 2013:39:527-547.

62. Shindel AW, Mann MW, Lev RY, Senge Imann R, Petersen J, Hruza GJ, Brandes SB. Mohs micrographic surgery for penile cancer: management and long-term follow up. J Urol. 2007;178(5):1980-1985.

63. López Alcina E, Rodrigo Aliaga M, Martínez Sarmiento M, Monserrat Monfort JJ, Rivas Rodero S, Jiménez CF. Verrucous carcinoma of the penis. Actas Urol Esp. 1996;20(6):560-3.

64. Ricós Torrent JV, Casanova Ramón-Borja J, Iborra Juan I, Monros Lliso JL, Dumont Martínez R, Solsona Nárbon E. Verrucous carcinoma of the penis. Report of 8 cases. Actas Urol Esp. 1990;14(6):410-412.

65. Clemente Ramos LM, Maganto Pavón E, García González R, Burgos Revilla FJ, Fernández Cañadas S, Crespo Martínez L, Castañeda Casanova A, Escudero Barrilero A. Verrucous carcinoma of the penis. A report of 6 new cases and a review of the diagnostic and therapeutic aspects. Actas Urol Esp. 1997;21(4):372-376.

66. Hughes PS. Cryosurgery of verrucous carcinoma of the penis (BuschkeLowenstein tumor). Cutis. 1979;24(1):43-5

67. Nishikawa Y, Maruoka M, Miyauchi T, Nagayama T, Komatsu T, Matsuzak O. Verrucous carcinoma of the penis: a case report and MRI findings. Hinyokika Kiyo. 1993;39(6):573-5.

68. Shimizu A, Tamura A, Ishikawa O. Invasive squamous cell carcinoma arising from verrucous carcinoma. Recognition of verrucous carcinoma of skin as an in situ carcinoma. Eur J Dermatol 2006;16(4):439-442.

\section{Publisher's Note}

Springer Nature remains neutral with regard to jurisdictional claims in published maps and institutional affiliations. 